\title{
Clinical impact of cardiovascular disease on patients with bronchiectasis
}

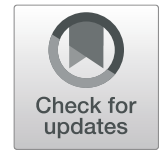

\author{
Shanshan Chen", Aimin Qiu, Zhang Tao and Hailin Zhang
}

\begin{abstract}
Background: Patients with bronchiectasis have a higher cardiovascular risk than their matched controls. However, the effect of cardiovascular (CV) disease on bronchiectasis remains unclear. Thus, we aimed to investigate the clinical impacts of cardiovascular disease on adult patients with bronchiectasis.

Methods: The study cohort comprised 603 consecutive inpatients diagnosed with bronchiectasis in the Affiliated Yancheng Hospital of Southeast University Medical College (Jiangsu, China) from January 2014 to December 2017. Symptoms, bacterial cultures, blood biochemical indicator levels, and chest high-resolution computed tomography scans were assessed during their initial hospitalization for bronchiectasis. Three hundred and thirty five subjects finished 1 year follow-up after their hospital discharge.
\end{abstract}

Results: Three hundred thirty five patients had at least one bronchiectasis exacerbation during the 1-year follow-up period. Patients with CV comorbidities were more likely to present with symptoms of wheezing (65.3\%) and had a higher levels of brain natriuretic peptide $(P<0.001)$ and $D$-dimer $(P<0.001)$ than those without $C V$ comorbidities. Independent risk factors associated with bronchiectasis exacerbations were the presence of comorbidities of cardiovascular diseases (odds ratio [OR] 2.503, 95\% confidence interval [CI] 1.298-4.823; $P=0.006$ ), the isolation of Pseudomonas aeruginosa (OR 2.076, 95\% Cl 1.100-3.919; $P=0.024$ ), and extension to more than two lobes (OR $2.485,95 \% \mathrm{Cl} 1.195-5.168 ; P=0.015)$.

Conclusion: The existence of cardiovascular disease was independently associated with increased bronchiectasis exacerbation.

Keywords: Bronchiectasis, Cardiovascular disease, Exacerbation, Clinical impact

\section{Background}

Bronchiectasis is defined as the irreversible dilatation and thickening of bronchi, and it is diagnosed using high-resolution computed tomography (HRCT) as the recognized gold standard [1,2]. Advances in CT technology have improved the detection and characterization of bronchiectasis and its complications [3]. Although the prevalence remains unknown in most areas, research has shown an increase in the incidence and prevalence of bronchiectasis [4]. Exacerbations that present with acute

\footnotetext{
*Correspondence: css901211@163.com

Department of Respiratory and Critical Care Medicine, Yancheng Third People's Hospital, The Affiliated Yancheng Hospital of Southeast University Medical College, Yancheng, Jiangsu, China
}

deterioration and worsening of local symptoms usually lead to hospitalization $[1,2,5]$.

Comorbidities including cardiovascular (CV) disease, rheumatoid arthritis, and chronic kidney disease are commonly present in patients with bronchiectasis and significantly contribute to the disease burden and mortality [6]. Several studies have suggested a high prevalence of CV disease [7] and cardiac dysfunction [8] in bronchiectasis patients. Previous study has also shown increased arterial stiffness in patients with bronchiectasis, compared to their matched controls [9], and these patients have a higher risk of CV disease [10-12]. Interestingly, cardiovascular disease seemed to be linked to bronchiectasis, as it is to other diseases that feature

(c) The Author(s). 2020 Open Access This article is licensed under a Creative Commons Attribution 4.0 International License, which permits use, sharing, adaptation, distribution and reproduction in any medium or format, as long as you give appropriate credit to the original author(s) and the source, provide a link to the Creative Commons licence, and indicate if changes were made. The images or other third party material in this article are included in the article's Creative Commons licence, unless indicated otherwise in a credit line to the material. If material is not included in the article's Creative Commons licence and your intended use is not permitted by statutory regulation or exceeds the permitted use, you will need to obtain permission directly from the copyright holder. To view a copy of this licence, visit http://creativecommons.org/licenses/by/4.0/ The Creative Commons Public Domain Dedication waiver (http://creativecommons.org/publicdomain/zero/1.0/) applies to the data made available in this article, unless otherwise stated in a credit line to the data. 
increased systemic inflammation [13]. Previous research has reported a relationship between elevated cardiovascular risk and higher exacerbation frequency in chronic obstructive pulmonary disease (COPD) [14, 15], in addition, the calcification of coronary artery is raised in COPD patients and is related to a higher morbidity and mortality [16]. However, few studies have assessed the impact of $\mathrm{CV}$ disease on the exacerbation of bronchiectasis.

Research is warranted to obtain a deeper understanding of the relationship between CV disease and bronchiectasis and further reduce the risk of acute exacerbations in bronchiectasis. Therefore, this study aimed to evaluate the clinical characteristics of bronchiectasis patients with and without CV disease, and analyse the impacts of $\mathrm{CV}$ disease on bronchiectasis exacerbation.

\section{Methods}

\section{Subjects}

A retrospective cohort study was conducted on inpatients diagnosed with bronchiectasis in the Affiliated Yancheng Hospital of Southeast University Medical College (Jiangsu, China) from January 2014 to December 2017. Bronchiectasis was confirmed based on a radiological diagnosis established using HRCT and a clinical history consistency. Patients who had not undergone a chest HRCT scan examination or had indecipherable HRCT scan images were excluded. Patients with active malignancy, cystic fibrosis, significant immunodeficiency, or traction bronchiectasis resulting from pulmonary fibrosis/sarcoidosis were also excluded. Patients were also excluded if they had received long-term oral or inhaled antibiotic therapy. The study was approved by the Yancheng Third People's Hospital ethics committee and was executed following the relevant guidelines and regulations.

\section{Diagnosis of bronchiectasis and CV disease}

The diagnostic criteria for bronchiectasis are based on chest HRCT scans and clinical symptoms (coughing and expectoration or long durations of hemoptysis). During full inspiration, high-resolution scans from the apex to the base of the lungs were obtained at 1-milimeter collimation and 10- milimeter intervals. Bronchiectasis was diagnosed according to the following criteria: 1) a lack of bronchi taper 2) the internal diameter of bronchi dilation was greater than the next pulmonary artery or 3 ) within $1 \mathrm{~cm}$ of the costal or the adjacent mediastinal pleural surface, a visualization of the peripheral bronchi $[17,18]$. The type of bronchiectasis was conformed morphologically. The bronchiectasis exacerbation was diagnosed based on deterioration in three or more of the following main symptoms for $48 \mathrm{~h}$ at least: cough, sputum volume or sputum consistency, purulent sputum, breathlessness or exercise tolerance, fatigue or malaise, hemoptysis, and the requirement of a change in the bronchiectasis treatment as determined by a clinician [19]. CV disease was a composite outcome of having a history of coronary heart disease (CHD) (acute coronary syndromes, chronic coronary artery disease), cerebrovascular events (including ischemic stroke, hemorrhagic stroke, or transient ischemic attack), peripheral artery disease or heart failure [20].

\section{Variables}

We collected information regarding the following variables in this study: general and anthropometric information (i.e., age, gender, body mass index); smoking history; a history of having respiratory illness (e.g., nasosinusitis, tuberculosis [TB], pneumonia.) and clinical manifestation (e.g., symptom onset, chronic expectoration properties, the presence of wheezing); a history of comorbidities (e.g., coronary heart disease, hypertension, diabetes); chest HRCT scan (the number of bronchiectatic lobes); laboratory parameters (e.g., C-reactive protein, erythrocyte sedimentation rate, neutrophil percentage); and sputum microbiological examination (sputum specimens were eligible if they contained $<10$ squamous epithelial cells and $>25$ leukocytes per low-powered field). Exacerbations were recorded in bronchiectasis patients within 1 year after their hospital discharge, using face-toface interviews during their outpatient service.

\section{Statistics}

The statistical package SPSS version 22.0 was used for statistical analyses, and GraphPad Prism 5 Software was used for drawing graphs. All quantitative variables were listed as the mean \pm standard deviation (SD) values, and the qualitative variables were listed as absolute numbers and percentages. The distribution of the variables was analysed using the Kolmogorov-Smirnov test. In the bivariate analysis, the $\mathrm{t}$-test for independent variables was used to analyse the variables with normal distribution, and the Mann-Whitney $U$ test was used in other cases. The chi-squared test was used to compare qualitative variables. Depending on whether the variables were distributed normally or non-normally, the correlation between variables was assessed by calculating Spearman or Pearson coefficient. In the case of elevated collinearity between two variables (Spearman correlation test $>0.6$ ), the variable with greater clinical significance was included in the final regression eq. A logistic regression model was used to evaluate the related factors of bronchiectasis exacerbation. The variables that presented statistically significant differences $(p<0.05)$ in the bivariate analysis were included as the independent variables in the model. Thereafter, using the forward stepwise 
technique (the Wald test) to remove any variables with $p>0.1$ from the final model. The odds ratio (OR) and 95\% confidence interval for independent variables were calculated.

\section{Results}

A total of 603 bronchiectasis patients (404 with only bronchiectasis and 199 bronchiectasis patients with CV disease) were included in the study. Among these 603 patients, 345 of the included patients completed a 1-year follow-up. One hundred forty-two patients had at least one bronchiectasis exacerbation within 1 year of hospital discharge.

The CV comorbidities and baseline characteristics of the patients are shown in Tables 1 and 2; the laboratory parameters are shown in Tables 3. There were several significant differences in the previous history, clinical symptoms, radiological signs, and blood biochemical indicator levels of the two groups. More patients (20.6\%) in the group with co-existing $\mathrm{CV}$ disease tended to have a history of TB. Patients with CV comorbidities most commonly presented with symptoms of wheezing (65.3\%) whereas those patients with no CV comorbidity more frequently presented with hemoptysis (44.6\%). Further, patients with $\mathrm{CV}$ comorbidities had a higher level of brain natriuretic peptide and D-dimer, which are important indicators for assessing the severity of $\mathrm{CV}$ disease. Although there were significant differences in the levels of $\mathrm{PO}_{2}$ and $\mathrm{PCO}_{2}$ between the two groups, no significant clinical value was observed.

Figures 1 and 2 show the differential characteristics of patients with at least one exacerbation and patients with no exacerbation. Patients with one or more exacerbations had worse HRCT scan images that showed more cystic bronchiectasis and involved a wider region of affected lobes or segments, a higher prevalence of CV disease comorbidities, more positive cultures of P.aeruginosa

Table 1 Cardiovascular comorbidities in bronchiectasis patients

\begin{tabular}{ll}
\hline CV comorbidities & No. (\%) \\
\hline CHD & \\
$\begin{array}{l}\text { acute coronary syndromes } \\
\text { chronic coronary artery disease }\end{array}$ & $23(11.56 \%)$ \\
$\begin{array}{l}\text { Cerebrovascular events } \\
\text { ischemic stroke }\end{array}$ & $37(18.59 \%)$ \\
hemorrhagic stoke & $8(4.02 \%)$ \\
transient ischemic attack & $58(29.15 \%)$ \\
Peripheral artery disease & $24(12.06 \%)$ \\
Heart failure & $29(14.57 \%)$ \\
\hline $\begin{array}{l}\text { Total number of comorbidities add up to greater than the total number of } \\
\text { patients because some patients developed more than one comorbidity }\end{array}$
\end{tabular}

Table 2 Baseline and clinical characteristics of subjects with bronchiectasis, with and without cardiovascular disease

\begin{tabular}{|c|c|c|c|}
\hline Parameter & $\begin{array}{l}\text { Bronchiectasis } \\
(n=404)\end{array}$ & $\begin{array}{l}\text { Bronchiectasis with } \\
\text { cardiovascular } \\
\text { disease }(n=199)\end{array}$ & $P$-value \\
\hline Age, years & $61.97 \pm 11.17$ & $65.35 \pm 9.75$ & 0.107 \\
\hline Sex male: female $n$ & 191:213 & $80: 119$ & 0.1 \\
\hline $\mathrm{BMI}, \mathrm{kg} / \mathrm{m}^{2}$ & $23.81 \pm 3.45$ & $23.51 \pm 3.22$ & 0.591 \\
\hline Smoking & $17.6 \%$ & $16.6 \%$ & 0.762 \\
\hline Previous pneumonia & $38.9 \%$ & $33.2 \%$ & 0.173 \\
\hline Previous tuberculosis & $12.4 \%$ & $20.6 \%$ & 0.008 \\
\hline $\begin{array}{l}\text { Previous anaphylactic } \\
\text { rhinitis }\end{array}$ & $2.2 \%$ & $1.5 \%$ & 0.552 \\
\hline \multicolumn{4}{|l|}{ Presenting symptoms } \\
\hline Cough & $70.3 \%$ & $73.4 \%$ & 0.433 \\
\hline Wheezing & $51.2 \%$ & $65.3 \%$ & 0.001 \\
\hline Hemoptysis & $44.6 \%$ & $34.7 \%$ & 0.02 \\
\hline P.aeruginosa isolation & $22.8 \%$ & $30.2 \%$ & 0.063 \\
\hline \multicolumn{4}{|l|}{ Type } \\
\hline Cylindrical & $28.2 \%$ & $22.6 \%$ & 0.142 \\
\hline Cystic & $35.1 \%$ & $40.7 \%$ & 0.184 \\
\hline Mixed & $36.6 \%$ & $36.7 \%$ & 0.99 \\
\hline \multicolumn{4}{|l|}{ Location } \\
\hline Unilateral & $25.0 \%$ & $26.1 \%$ & \\
\hline Bilateral & $75.0 \%$ & $73.9 \%$ & 0.764 \\
\hline \multicolumn{4}{|l|}{ Extent } \\
\hline Affected lobes n & $3.21 \pm 1.47$ & $3.12 \pm 1.43$ & 0.465 \\
\hline Affected segments $n$ & $8.50 \pm 5.15$ & $8.71 \pm 4.70$ & 0.011 \\
\hline
\end{tabular}

Data are presented as the mean \pm SD or $\%$, unless otherwise stated. $B M I$ body mass index. Data presented in bold type are statistically significant

isolation, and higher levels of $\mathrm{PCO}_{2}$ and D-dimer than patients with no exacerbation..

Table 4 summarizes the ORs and $95 \%$ confidence intervals of variables related to bronchiectasis exacerbations in all patients. The variables with $\mathrm{OR}=1$ involve no risk of bronchiectasis exacerbation. The presence of CV disease comorbidities $(P=0.006)$, P.aeruginosa isolation $(P=0.024)$, and extension to more than two lobes $(P=0.015)$ were independent risk factors for bronchiectasis exacerbation in these patients.

\section{Discussion}

The key findings of our study suggest that in non-cystic fibrosis bronchiectasis patients, the presence of cardiovascular diseases, the isolation of P.aeruginosa from sputum samples, and extension to more than two lobes were associated with an increased risk of bronchiectasis exacerbation.

This is a cross-sectional and observational study on the prevalence of $\mathrm{CV}$ disease with a large number of 
Table 3 Laboratory parameters of subjects with bronchiectasis with and without cardiovascular disease

\begin{tabular}{|c|c|c|c|}
\hline & $\begin{array}{l}\text { Bronchiectasis } \\
(n=404)\end{array}$ & $\begin{array}{l}\text { Bronchiectasis } \\
\text { with cardiovascular } \\
\text { disease }(n=199)\end{array}$ & $P$-value \\
\hline$\overline{W B C}, \times 10^{9}$ cells $/ L$ & $8.40 \pm 5.03$ & $8.82 \pm 4.11$ & 0.551 \\
\hline Neutrophils, \% & $72.59 \pm 12.05$ & $75.48 \pm 10.10$ & 0.003 \\
\hline Haemoglobin, g/L & $123.05 \pm 19.74$ & $125.56 \pm 22.44$ & 0.329 \\
\hline Platelet, $\times 10^{9}$ cells $/ \mathrm{L}$ & $196.89 \pm 83.96$ & $195.24 \pm 88.47$ & 0.480 \\
\hline$C R P, I U / m L$ & $28.53 \pm 44.69$ & $29.89 \pm 38.82$ & 0.168 \\
\hline $\mathrm{ESR}, \mathrm{mm} / \mathrm{h}$ & $41.07 \pm 29.18$ & $36.03 \pm 30.61$ & 0.168 \\
\hline Albumin, mg/dL & $37.90 \pm 5.09$ & $36.86 \pm 4.28$ & 0.095 \\
\hline $\mathrm{K}^{+}, \mathrm{mmol} / \mathrm{L}$ & $3.98 \pm 0.47$ & $4.05 \pm 0.61$ & 0.009 \\
\hline $\mathrm{Na}^{+}, \mathrm{mmol} / \mathrm{L}$ & $140.18 \pm 4.51$ & $139.52 \pm 4.30$ & 0.468 \\
\hline $\mathrm{Cl}^{-}, \mathrm{mmol} / \mathrm{L}$ & $99.41 \pm 5.23$ & $96.09 \pm 7.10$ & 0.001 \\
\hline $\mathrm{Ca}^{+}, \mathrm{mmol} / \mathrm{L}$ & $2.22 \pm 0.36$ & $2.20 \pm 0.14$ & 0.697 \\
\hline $\mathrm{BUN}, \mathrm{mol} / \mathrm{L}$ & $5.55 \pm 3.35$ & $6.04 \pm 3.36$ & 0.069 \\
\hline $\begin{array}{l}\text { Blood glucose, } \\
\mathrm{mmol} / \mathrm{L}\end{array}$ & $6.23 \pm 2.47$ & $6.56 \pm 2.58$ & 0.062 \\
\hline BNP, pg/L & $1365.22 \pm 2996.11$ & $3602.01 \pm 6297.81$ & $<0.001$ \\
\hline Cholesterol, mol/L & $4.09 \pm 0.97$ & $4.16 \pm 1.84$ & 0.171 \\
\hline Triglyceride, mol/L & $1.16 \pm 0.67$ & $1.13 \pm 0.60$ & 0.772 \\
\hline D-dimer, mg/L & $0.69 \pm 1.105$ & $1.00 \pm 1.676$ & $<0.001$ \\
\hline $\mathrm{PO}_{2}, \mathrm{kPa}$ & $10.11 \pm 3.20$ & $10.26 \pm 3.50$ & 0.018 \\
\hline $\mathrm{PCO}_{2}, \mathrm{kPa}$ & $6.59 \pm 1.69$ & $7.34 \pm 1.83$ & 0.02 \\
\hline $\mathrm{SO}_{2}, \%$ & $92.95 \pm 7.55$ & $92.19 \pm 7.15$ & 0.271 \\
\hline
\end{tabular}

Data are presented as the mean $\pm S D$ or $\%$, unless otherwise stated. WBC white blood count, CRP C-reactive protein, ESR erythrocyte sedimentation rate, $B U N$ serum urea nitrogen, $B N P$ brain natriuretic peptide, $P O 2$ oxygen tension, $P C O 2$ carbon dioxide tension, $\mathrm{SO} 2$ oxygen saturation. The data presented in bold type are statistically significant

bronchiectasis patients from China. Several studies have also reported a high prevalence of $\mathrm{CV}$ disease in patients with bronchiectasis that varies according to the population that is analysed [7-9]. A historical cohort analysis has demonstrated a causal link between the two diseases, suggesting a higher risk of $\mathrm{CV}$ disease in patients with bronchiectasis [10-12]. Moreover, excess CV risk is associated with greater bronchiectasis severity [11], frequency deterioration, impaired lung function [12]. Our results confirmed a high prevalence of $\mathrm{CV}$ disease in bronchiectasis patients, which is consistent with published research.

The possible mechanisms for the increased CV disease prevalence need further exploration. Bronchiectasis is characterized by chronic inflammation and dysfunction of clear airway secretions, leading to recurrent infection. Previous studies have reported that bronchiectasis patients have increased systemic inflammation [21-23], such as increased vascular adhesion molecules [24, 25], which plays a crucial role in the development of atherosclerosis [26] and is associated with vulnerable atherosclerotic plaque and subsequent thromboembolic events [27, 28]. Moreover, the higher prevalence of acute infections in bronchiectasis patients may also be associated with a transient increase in the risk of vascular events [29]. In addition, Gale and colleagues have shown increased arterial stiffness in bronchiectasis, which is a well-acknowledged risk factor for vascular disease [9].

We next explored the clinical characteristics of bronchiectasis subjects with and without cardiovascular disease. The group of patients who had bronchiectasis with $\mathrm{CV}$ disease were more likely to have a history of previous tuberculosis, which is consistent with recent epidemiological work that the risk of CVD in persons who develop tuberculosis is higher than that in persons without a history of tuberculosis [30-33]. Together, these data indicate that tuberculosis may play a part in the CVD pathogenesis, and further research is necessary to investigate the potential connection between tuberculosis, bronchiectasis and CVD. In the current study, we also found that patients with CV comorbidities had a higher level of brain natriuretic peptide and D-dimer. Brain natriuretic peptide (BNP) is a marker of myocardial and circulatory stress that can predict future cardiac events and death in asymptomatic populations [34]. The natriuretic peptides have an essential role in vascular function and remodeling by increasing nitric oxide effects [35], inhibiting lipid insulation in the vascular wall [36], and increasing parasympathetic tension [37]. Plasma D-dimer, a fibrin degradation product, is another important predictor of stroke [38, 39], CHD [38], VTE [40, 41], and CVD [42]. However, between D-dimer and cardiovascular risk factors, their pathophysiology has not been fully comprehended. Neil et al. found that the association of D-dimer with cardiovascular disease did not depend on elevated inflammatory biomarkers, demonstrating that D-dimer may shed light on different pathophysiologies of cardiovascular disease by type and race [39]. Future studies are needed to address the role played by brain natriuretic peptide and D-dimer in bronchiectasis.

The exacerbation of bronchiectasis is a crucial target for therapy given that it is a major determinant of the cost of healthcare [1]. Further, more severe and frequent exacerbations are associated with mortality [43]. Exacerbations are associated with increased airways and systemic inflammation [25] and progressive lung damage [43, 44], the exacerbations can be explained according to the vicious cycle of chronic bronchial infection, inflammation, impaired mucociliary clearance and structural lung damage [1]. In this study, the extent of bronchiectasis based on radiography and the isolation of P.aeruginosa from the sputum samples were associated with bronchiectasis exacerbation. The degree of bronchiectasis, quantified according to the number of affected 
A

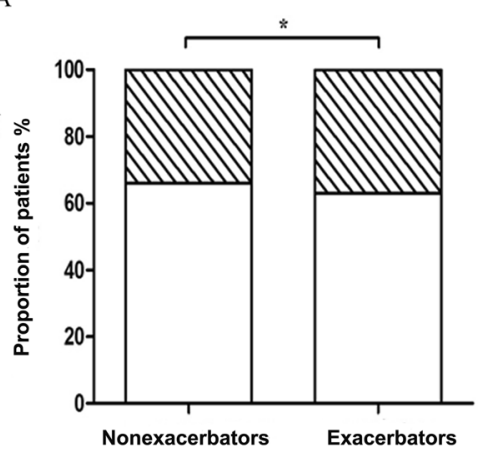

C

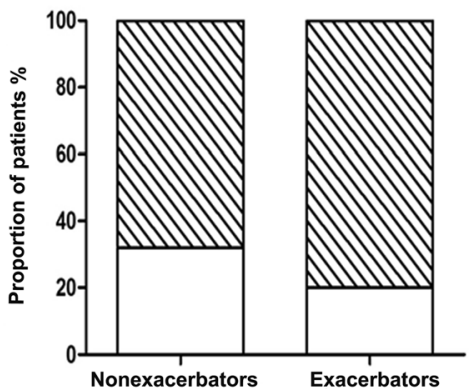

$\square$ Non-cystic

$\square$ Cystic

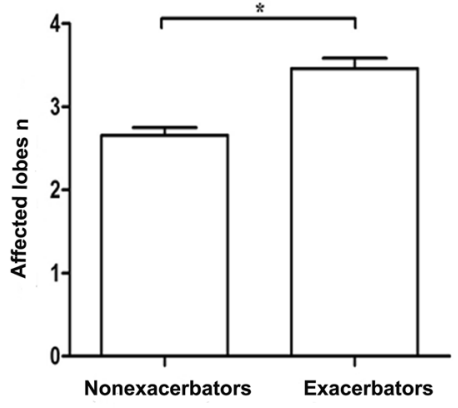

D
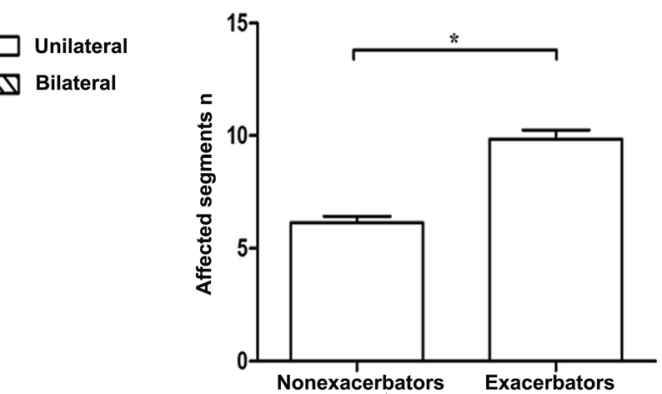

Fig. 1 a Proportion with cystic bronchiectasis; b number of affected lobules; c proportion with bilateral location; and (d) number of affected segments of patients who experienced exacerbation (at least once) and that of patients who did not experience an exacerbation. *: $P<0.05$

A

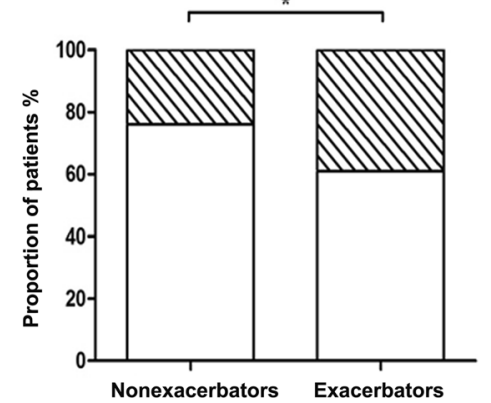

$\mathrm{C}$

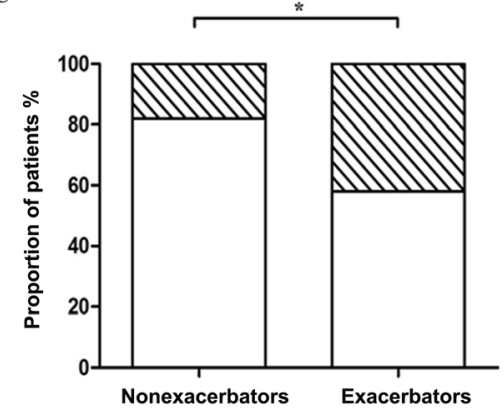

B

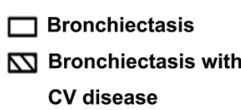

CV disease

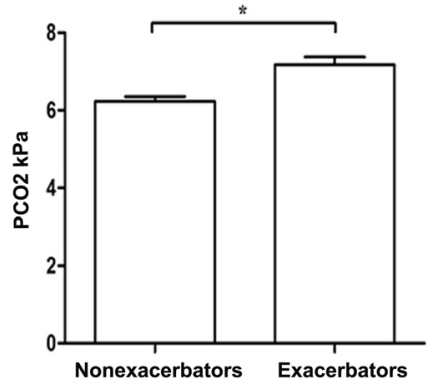

D

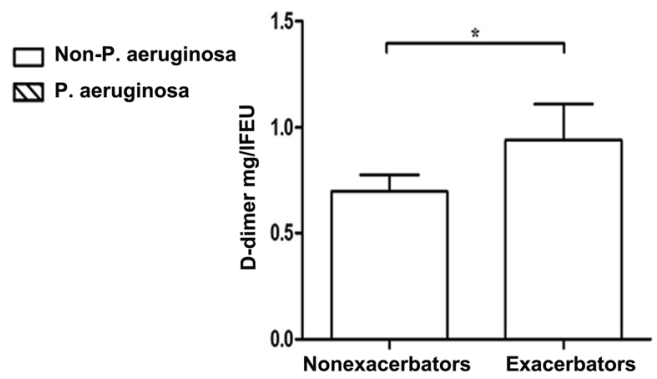

Fig. 2 a Proportion with cardiovascular disease; b level of $\mathrm{PCO}_{2}$; c proportion with P. aeruginosa isolation; and (d) level of D-dimer of patients who experienced at least one exacerbation and that of patients who did not experience an exacerbation. * $P<0.05$ 
Table 4 Factors associated with bronchiectasis exacerbation in all subjects according to the logistic regression analysis

\begin{tabular}{lll}
\hline & OR $(95 \% \mathrm{Cl})$ & $P$-value \\
\hline Co-existing CV diseases & $2.503(1.298-4.823)$ & $\mathbf{0 . 0 0 6}$ \\
P. aeruginosa isolation & $2.076(1.100-3.919)$ & $\mathbf{0 . 0 2 4}$ \\
Cystic & $1.369(0.695-2.697)$ & 0.364 \\
Bilateral & $0.929(0.394-2.188)$ & 0.866 \\
Extent > 2 lobes & $2.485(1.195-5.168)$ & $\mathbf{0 . 0 1 5}$ \\
Hypercapnia & $1.589(0.881-2.864)$ & 0.124 \\
Higher D-dimer level & $1.232(0.630-2.410)$ & 0.542
\end{tabular}

Factors associated with bronchiectasis exacerbation in all subjects according to the logistic regression analysis. $C V$ diseases: cardiovascular diseases; $P$. aeruginosa Pseudomonas aeruginosa

lobes, was included in the analysis. This is consistent with the result of a previous study wherein pulmonary extension could be used to evaluate the severity of bronchiectasis [45]. P.aeruginosa was an independent factor associated with bronchiectasis exacerbation in the present study, which is supported by previous researches $[46,47]$. In our study, compared with bronchiectasis alone, patients with $\mathrm{CV}$ disease were 2.503 times more likely to experience exacerbation, independent of other variables. The underlying reason for increased exacerbation in bronchiectasis with $\mathrm{CV}$ disease remains unclear, it could be because they share similar risk factors, such as systemic inflammation or acute infection. Further studies are warranted to demonstrate the biological mechanism between $\mathrm{CV}$ disease and the exacerbation of bronchiectasis.

There are certain limitations of this study. The first limitation was the possibility of selection bias due to the retrospective study design. Thus, we conducted a crosssectional and observational study that may minimize the risk of selection bias. Second, pulmonary function test results are shown to be associated with poor prognosis in bronchiectasis patients [48]; however, this study does not include pulmonary function tests. A previous study has shown that serial CT changes were correlated with the pulmonary function trends [44]; hence, we used CT findings to evaluate the severity of bronchiectasis. Third, we did not consider the treatment status in the analysis for patient compliance; this may have affected the results. Finally, the generalizability of our findings may be limited because of the single-centre design; therefore, our findings require additional validation, including data from other countries and institutions.

\section{Conclusion}

In summary, our results suggest that the existence of cardiovascular disease was independently associated with increased bronchiectasis exacerbation. Awareness and the mitigation of existing cardiovascular disease may have the potential to reduce exacerbation and require further study to improve clinical outcomes in bronchiectasis.

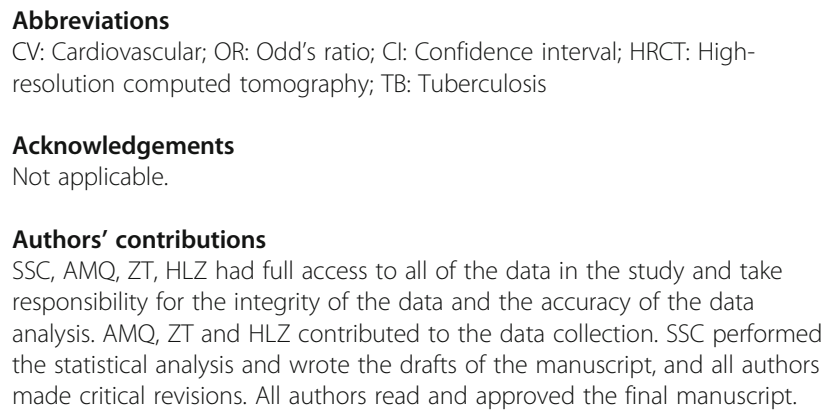

\section{Acknowledgements}

Not applicable.

Authors' contributions

SSC, AMQ, ZT, HLZ had full access to all of the data in the study and take responsibility for the integrity of the data and the accuracy of the data analysis. AMQ, ZT and HLZ contributed to the data collection. SSC performed the statistical analysis and wrote the drafts of the manuscript, and all authors made critical revisions. All authors read and approved the final manuscript.

Funding

No funding.

\section{Availability of data and materials}

The datasets used and/or analysed during the present study are available from the corresponding author on reasonable request.

\section{Ethics approval and consent to participate}

The Yancheng Third People's Hospital ethics committee approved the study (YCSY201909). All patients provided written informed consent.

\section{Consent for publication}

Not applicable.

\section{Competing interests}

The authors declare that they have no competing interests.

Received: 24 July 2019 Accepted: 6 April 2020

Published online: 23 April 2020

\section{References}

1. Polverino E, Goeminne PC, McDonnell MJ, Aliberti S. European Respiratory Society guidelines for the management of adult bronchiectasis. Eur Respir J. 2017:50:1700629.

2. Hill AT, Sullivan AL, Chalmers JD, De Soyza A, Elborn SJ, Floto AR, Grillo L, Gruffydd-Jones K, Harvey A, Haworth CS, et al. British Thoracic Society guideline for bronchiectasis in adults. Thorax. 2019;74:1-69.

3. Dodd JD, Lavelle LP, Fabre A, Brady D. Imaging in cystic fibrosis and noncystic fibrosis bronchiectasis. Semin Respir Crit Care Med. 2015;36:194-206

4. Quint JK, Millett ER, Joshi M, Navaratnam V, Thomas SL, Hurst JR, Smeeth L, Brown JS. Changes in the incidence, prevalence and mortality of bronchiectasis in the UK from 2004 to 2013: a population-based cohort study. Eur Respir J. 2016;47:186-93.

5. Pasteur MC, Bilton D, Hill AT. British Thoracic Society guideline for non-CF bronchiectasis. Thorax. 2010;65:577.

6. McDonnell MJ, Aliberti S, Goeminne PC, Restrepo MI, Finch S, Pesci A, Dupont $L$, Fardon TC, Wilson R, Loebinger MR, et al. Comorbidities and the risk of mortality in patients with bronchiectasis: an international multicentre cohort study. Lancet Respir Med. 2016;4:969-79.

7. Onen ZP, Gulbay BE, Sen E, Yildiz OA, Saryal S, Acican T, Karabiyikoglu G. Analysis of the factors related to mortality in patients with bronchiectasis. Respir Med. 2007;101:1390-7.

8. Alzeer AH, Al-Mobeirek AF, Al-Otair HA, Elzamzamy UA, Joheriy IA, Shaffi AS. Right and left ventricular function and pulmonary artery pressure in patients with bronchiectasis. Chest. 2008;133:468-73.

9. Gale NS, Bolton CE, Duckers JM, Enright S, Cockcroft JR, Shale DJ. Systemic comorbidities in bronchiectasis. Chron Respir Dis. 2012;9:231-8.

10. Navaratnam V, Millett ER, Hurst JR, Thomas SL, Smeeth L, Hubbard RB, Brown J, Quint JK. Bronchiectasis and the risk of cardiovascular disease: a population-based study. Thorax. 2017;72:161-6.

11. Evans IE, Bedi P, Quinn TM, Hill AT. Bronchiectasis severity is an independent risk factor for vascular disease in a bronchiectasis cohort. Chest. 2017;151:383-8. 
12. Saleh AD, Kwok B, Brown JS, Hurst JR. Correlates and assessment of excess cardiovascular risk in bronchiectasis. Eur Respir J. 2017;50:1701127.

13. Kaptoge S, Di Angelantonio E, Pennells L, Wood AM, White IR, Gao P, Walker M, Thompson A, Sarwar N, Caslake M, et al. C-reactive protein, fibrinogen, and cardiovascular disease prediction. N Engl J Med. 2012;367: 1310-20.

14. McAllister DA, Maclay JD, Mills NL, Leitch A, Reid P, Carruthers R, O'Connor J, McAlpine L, Chalmers G, Newby DE, et al. Diagnosis of myocardial infarction following hospitalisation for exacerbation of COPD. Eur Respir J. 2012;39: 1097-103.

15. Patel AR, Kowlessar BS, Donaldson GC, Mackay AJ, Singh R, George SN, Garcha DS, Wedzicha JA, Hurst JR. Cardiovascular risk, myocardial injury, and exacerbations of chronic obstructive pulmonary disease. Am J Respir Crit Care Med. 2013;188:1091-9.

16. Williams MC, Murchison JT, Edwards LD, Agusti A, Bakke P, Calverley PM, Celli B, Coxson HO, Crim C, Lomas DA, et al. Coronary artery calcification is increased in patients with COPD and associated with increased morbidity and mortality. Thorax. 2014;69:718-23.

17. Naidich DP, McCauley DI, Khouri NF, Stitik FP, Siegelman SS. Computed tomography of bronchiectasis. J Comput Assist Tomogr. 1982;6:437-44.

18. Martinez-Garcia MA, de la Rosa CD, Soler-Cataluna JJ, Donat-Sanz Y, Serra PC, Lerma MA, Ballestin J, Sanchez IV, Selma Ferrer MJ, Dalfo AR, Valdecillos MB. Prognostic value of bronchiectasis in patients with moderate-to-severe chronic obstructive pulmonary disease. Am J Respir Crit Care Med. 2013;187: 823-31.

19. Hill AT, Haworth CS, Aliberti S. Pulmonary exacerbation in adults with bronchiectasis: a consensus definition for clinical research. Eur Respir J. 2017;49:1700051.

20. D'Agostino RB Sr, Vasan RS, Pencina MJ, Wolf PA, Cobain M, Massaro JM, Kannel WB. General cardiovascular risk profile for use in primary care: the Framingham heart study. Circulation. 2008;117:743-53.

21. Ip M, Lam WK, Chan JC, Liong E. Systemic effects of inflammation in bronchiectasis. Respir Med. 1991;85:521-5.

22. Wilson CB, Jones PW, O'Leary CJ, Hansell DM, Dowling RB, Cole PJ, Wilson R. Systemic markers of inflammation in stable bronchiectasis. Eur Respir J. 1998;12:820-4

23. Martinez-Garcia MA, Perpina-Tordera M, Roman-Sanchez P, Soler-Cataluna JJ, Carratala A, Yago M, Pastor MJ. The association between bronchiectasis, systemic inflammation, and tumor necrosis factor alpha. Arch Bronconeumol. 2008;44:8-14.

24. Zheng L, Tipoe G, Lam WK, Leung RY, Ho JC, Shum IH, Ooi GC, Ip MS, Tsang KW. Up-regulation of circulating adhesion molecules in bronchiectasis. Eur Respir J. 2000;16:691-6.

25. Chalmers JD, Smith MP, MCHugh BJ, Doherty C, Govan JR, Hill AT. Shortand long-term antibiotic treatment reduces airway and systemic inflammation in non-cystic fibrosis bronchiectasis. Am J Respir Crit Care Med. 2012;186:657-65.

26. Libby P, Ridker PM, Maseri A. Inflammation and atherosclerosis. Circulation. 2002:105:1135-43.

27. Nighoghossian N, Derex L, Douek P. The vulnerable carotid artery plaque: current imaging methods and new perspectives. Stroke. 2005;36:2764-72.

28. Tang TY, Howarth SP, Miller SR, Graves MJ, U-King-Im JM, Trivedi RA, Li ZY, Walsh SR, Brown AP, Kirkpatrick PJ, et al. Comparison of the inflammatory burden of truly asymptomatic carotid atheroma with atherosclerotic plaques contralateral to symptomatic carotid stenosis: an ultra small superparamagnetic iron oxide enhanced magnetic resonance study. J Neurol Neurosurg Psychiatry. 2007;78:1337-43.

29. Smeeth $L$, Thomas SL, Hall AJ, Hubbard R, Farrington P, Vallance P. Risk of myocardial infarction and stroke after acute infection or vaccination. $\mathrm{N}$ Engl J Med. 2004:351:2611-8.

30. Sheu JJ, Chiou HY, Kang JH, Chen YH, Lin HC. Tuberculosis and the risk of ischemic stroke: a 3-year follow-up study. Stroke. 2010:41:244-9.

31. Chung WS, Lin CL, Hung CT, Chu YH, Sung FC, Kao CH, Yeh JJ. Tuberculosis increases the subsequent risk of acute coronary syndrome: a nationwide population-based cohort study. Int J Tuberc Lung Dis. 2014;18:79-83.

32. Huaman MA, Henson D, Ticona E, Sterling TR, Garvy BA. Tuberculosis and cardiovascular disease: linking the epidemics. Trop Dis Travel Med Vaccines. 2015;1:10.

33. Huaman MA, Kryscio RJ, Fichtenbaum CJ, Henson D, Salt E, Sterling TR, Garvy BA. Tuberculosis and risk of acute myocardial infarction: a propensity score-matched analysis. Epidemiol Infect. 2017;145:1363-7.
34. Wang TJ, Larson MG, Levy D, Benjamin EJ, Leip EP, Omland T, Wolf PA, Vasan RS. Plasma natriuretic peptide levels and the risk of cardiovascular events and death. N Engl J Med. 2004;350:655-63.

35. Brunner F, Wolkart $G$. Relaxant effect of $C$-type natriuretic peptide involves endothelium and nitric oxide-cGMP system in rat coronary microvasculature. Cardiovasc Res. 2001:51:577-84.

36. Kohno M, Yokokawa K, Yasunari K, Kano H, Minami M, Ueda M, Yoshikawa J. Effect of natriuretic peptide family on the oxidized LDL-induced migration of human coronary artery smooth muscle cells. Circ Res. 1997;81:585-90.

37. Herring N, Zaman JA, Paterson DJ. Natriuretic peptides like NO facilitate cardiac vagal neurotransmission and bradycardia via a cGMP pathway. Am J Physiol Heart Circ Physiol. 2001;281:H2318-27.

38. Folsom AR, Gottesman RF, Appiah D, Shahar E, Mosley TH. Plasma d-dimer and incident ischemic stroke and coronary heart disease: the atherosclerosis risk in communities study. Stroke. 2016;47:18-23.

39. Zakai NA, McClure LA, Judd SE, Kissela B, Howard G, Safford M, Cushman M. D-dimer and the risk of stroke and coronary heart disease. The REasons for geographic and racial differences in stroke (REGARDS) study. Thromb Haemost. 2017;117:618-24.

40. Cushman M, Folsom AR, Wang L, Aleksic N, Rosamond WD, Tracy RP, Heckbert SR. Fibrin fragment D-dimer and the risk of future venous thrombosis. Blood. 2003:101:1243-8.

41. Folsom AR, Alonso A, George KM, Roetker NS, Tang W, Cushman M Prospective study of plasma D-dimer and incident venous thromboembolism: the atherosclerosis risk in communities (ARIC) study. Thromb Res. 2015;136:781-5.

42. Zakai NA, Katz R, Jenny NS, Psaty BM, Reiner AP, Schwartz SM, Cushman M. Inflammation and hemostasis biomarkers and cardiovascular risk in the elderly: the cardiovascular health study. J Thromb Haemost. 2007;5:1128-35.

43. Chalmers JD, Goeminne P, Aliberti S, McDonnell MJ, Lonni S, Davidson J, Poppelwell L, Salih W, Pesci A, Dupont LJ, et al. The bronchiectasis severity index. An international derivation and validation study. Am J Respir Crit Care Med. 2014:189:576-85.

44. Sheehan RE, Wells AU, Copley SJ, Desai SR, Howling SJ, Cole PJ, Wilson R, Hansell DM. A comparison of serial computed tomography and functional change in bronchiectasis. Eur Respir J. 2002;20:581-7.

45. Martinez-Garcia MA, de Gracia J, Vendrell Relat M, Giron RM, Maiz Carro L, de la Rosa CD, Olveira C. Multidimensional approach to non-cystic fibrosis bronchiectasis: the FACED score. Eur Respir J. 2014;43:1357-67.

46. Chawla K, Vishwanath S, Manu MK, Lazer B. Influence of pseudomonas aeruginosa on exacerbation in patients with bronchiectasis. J Glob Infect Dis. 2015:7:18-22

47. Araujo D, Shteinberg M, Aliberti S. The independent contribution of Pseudomonas aeruginosa infection to long-term clinical outcomes in bronchiectasis. Eur Respir J. 2018;51:1701953.

48. Machado BC, Jacques PS, Penteado LP, Roth Dalcin PT. Prognostic factors in adult patients with non-cystic fibrosis bronchiectasis. Lung. 2018;196:691-7.

\section{Publisher's Note}

Springer Nature remains neutral with regard to jurisdictional claims in published maps and institutional affiliations.

Ready to submit your research? Choose BMC and benefit from

- fast, convenient online submission

- thorough peer review by experienced researchers in your field

- rapid publication on acceptance

- support for research data, including large and complex data types

- gold Open Access which fosters wider collaboration and increased citations

- maximum visibility for your research: over $100 \mathrm{M}$ website views per year

At BMC, research is always in progress.

Learn more biomedcentral.com/submission 